\title{
Переключение между одно- и двухволновой генерацией в волноводном Nd:YAG лазере с пассивной синхронизацией мод
}

\author{
М.В. Понарина ${ }^{*}$, А.Г. Охримчук, П.А. Образцов \\ Институт общей физики им. А.М. Прохорова РАН \\ *E-mail: ponarinamariya@gmail.com
}

DOI: 10.31868/RFL2020.209-210

Двухволновые лазеры представляют интерес для различных применений, таких как обеспечение оптической связи, лазерная локация, генерация ТГц излучения [1]. Одним из методов получения лазера с двумя длинами волн является использование кристаллов, в которых существуют несколько близлежащих излучательных переходов. Кристалл $\mathrm{Nd}$ :YAG является одним из таких кристаллов и наиболее широко используемой активной средой, благодаря своим превосходным оптическим и механическим свойствам.

В данной работе представлен компактный твердотельный $\mathrm{Nd}: \mathrm{YAG}$ лазер с диодной накачкой и новой волноводной архитектурой. Диаметр волновода, созданного в активном кристалле методом прямой записи пучком фемтосекундного лазера [2], составляет 20 мкм. Пассивная синхронизация мод осуществляется за счет насыщающегося поглотителя на основе графена, нанесенного на выходное зеркало резонатора [3]. Точная настройка внутрирезонаторного интерферометра, образующегося между активной средой и выходным зеркалом, позволяет контролировать спектрально-временные параметры выходного излучения [4]. Продемонстрирована работа лазера в режимах одно- (рис. 1 (а) и двухволновой (рис. 1 (б) генерации, а так же возможность переключения между ними с помощью прецизионного изменения длины резонатора.

a)
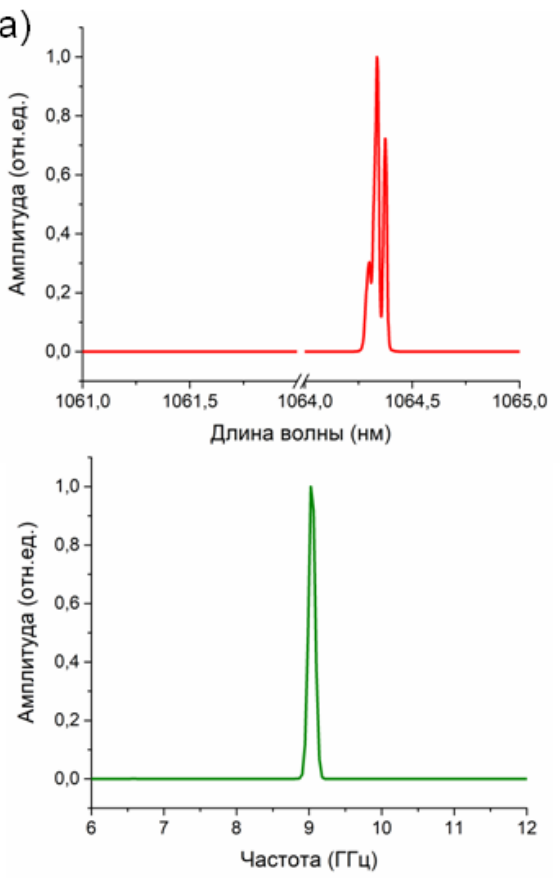

б)
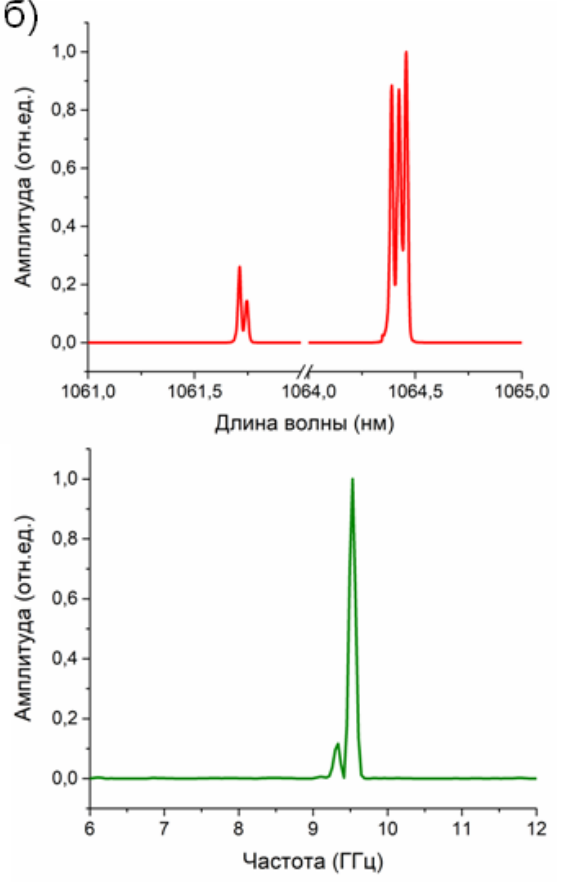

Рис. 1. Оптические и радиочастотные спектры, полученные при одно- (а) и двухволновой (б) генерации волноводной $\mathrm{Nd}: \mathrm{YAG}$ лазера 
Помимо этого в работе продемострирована возможность контролируемого переключения между режимами генерации волноводного $\mathrm{Nd}$ :YAG лазера за счет изменения поляризации излучения накачки. При использовании горизонтальной поляризации излучения накачки режим работы лазера приближен к режиму стабильной пассивной синхронизации мод. При использовании вертикальной поляризации излучения накачки выходная мощность излучения больше, чем при горизонтальной, но режим синхронизации мод не наблюдается.

Объединив преимущества каждой из линейных компонент поляризации накачки и контролируя величину внутрирезонаторных потерь, на длине волны 1064 нм получен режим пассивной синхронизации мод с частотой повторения импульсов 9.5 ГГц.

Исследование М.В. Понариной выполнено при финансовой поддержке РФФИ в рамках научного проекта № 19-32-90215. П.А. Образцов выражает благодарность Российскому научному фонду (РНФ № 19-72-00175).

\section{Литература}

[1] B.M. Walsh, Laser Phys. 20, 622-634 (2010)

[2] A. Okhrimchuk, V. Mezentsev, et al, Opt. Express, 20 (4), 3832-3843 (2012)

[3] A. Okhrimchuk, P. Obraztsov, Sci Rep 5, 11172 (2015)

[4] M. V. Ponarina, A. G. Okhrimchuk, et al, Quantum Electron, 49 (4), 365-370 (2019) 